\title{
Towards democratic consolidation in Africa? A look at the 28 November 2011 elections in the Democratic Republic of Congo
}

\author{
Mpfariseni Budeli* \\ Department of Mercantile Law, \\ University of South Africa, \\ P.O. Box 392, UNISA 0003, South Africa \\ E-mail: Budelm@unisa.ac.za \\ *Corresponding author
}

\author{
Andre Mbata B. Mangu \\ Department of Public, Constitutional and International Law, \\ University of South Africa, \\ P.O. Box 392, UNISA 0003, South Africa \\ E-mail: manguamb@unisa.ac.za \\ and \\ Faculté de Droit, \\ Université de Kinshasa, \\ BP 204, Kinshasa XI, Democratic Republic of Congo \\ E-mail: amangu@idgpa.org
}

\begin{abstract}
On 18 February 2006, President Joseph Kabila promulgated a new constitution for the Democratic Republic of Congo. This constitution was approved by referendum on 18-19 December 2005. It provides for a democratic state based on respect for the rule of law and the organisation of multiparty, free and fair elections. The 28 November 2011 elections were the second elections held under this constitution after the ones that took place in July 2006. This paper is based on the assumption that although democracy requires the holding of elections, the two concepts are not synonymous. Against this background, it critically reflects on the 28 November 2011 elections in Congo, the legislative framework that governed these elections, the results and the different reactions. It concludes that they were not free and fair and stresses the conditions for elections leading to democratic consolidation in this country and the rest of the African continent.
\end{abstract}

Keywords: Africa; African Union; democracy; democratic consolidation; elections; Democratic Republic of Congo; DRC; political parties; rule of law.

Reference to this paper should be made as follows: Budeli, M. and Mangu, A.M.B. (2013) 'Towards democratic consolidation in Africa? A look at the 28 November 2011 elections in the Democratic Republic of Congo', Int. J. Liability and Scientific Enquiry, Vol. 6, Nos. 1/2/3, pp.132-155.

Biographical notes: Mpfariseni Budeli received her $\mathrm{PhD}$ degree from the University of Cape Town and her Master of Laws degree (LLM) from the University of the North, currently University of Limpopo, Republic of South Africa. She is a Full Professor in the Department of Mercantile Law, College of 
Law, University of South Africa. She is also a Researcher rated with the National Research Foundation of the Republic of South Africa and a member of the South African Young Academy of Science. Her research interests include labour law, freedom of association, trade unions and politics.

Andre Mbata B. Mangu obtained his LLD and LLM degrees from the University of South Africa. He received his LLB degree from the University of Kinshasa. He is a Research Professor in the Department of Public, Constitutional and International Law, College of Law, University of South Africa. He is also a Researcher rated by the National Research Foundation of the Republic of South Africa and teaches constitutional law at the University of Kinshasa in the Democratic Republic of Congo. He has published extensively on constitutionalism, democracy, good governance, and the rule of law in Africa as well as on African politics.

\section{Introduction}

When its Constitutive Act was adopted in 1999 and came into operation in May 2002, the African Union (AU) replaced the Organisation of African Unity (OAU), which was established in 1963 after most African States acceded to independence in the early 1960s.

African Heads of State and Government of the Member States of the AU committed to 'promote and protect human and peoples' rights, to consolidate democratic institutions and culture, and to ensure good governance and the rule of law'. 'The AU objectives are inter alia to 'promote democratic principles and institutions, popular participation and good governance" ${ }^{2}$ while one of its major principles is 'respect for democratic principles, human rights, the rule of law and good governance'3. African leaders also adopted the Convention on Preventing and Combating Corruption (CPCC). ${ }^{4}$ This Convention indirectly promote free and fair elections by ensuring transparency, equity, and efficiency in the management of tendering and hiring procedures in the public service, ${ }^{5}$ by providing for the confiscation of proceeds or property derived from corruption or related offences, ${ }^{6}$ by incorporating the principle of transparency into the funding of political parties, ${ }^{7}$ by outlawing the use of funds acquired through illegal and corrupt practices to finance political parties, ${ }^{8}$ and by promoting the right of free access to information ${ }^{9}$.

Another important instrument in relation to elections is the Declaration on Democracy, Political, Economic and Corporate Governance (DDPECG). ${ }^{10}$ However, the most important regional instrument governing elections is the African Charter on Democracy, Elections (ACDEG). ${ }^{11}$

Every year since 2000, at least three African countries have been going to elections. In 2011, Cameroon, the DRC, Chad, Central African Republic, Seychelles, and Sao Tome \& Principe went to general elections. Congo, Lesotho, and more recently Angola have held their elections in 2012. Malawi is expected to go to polls by the end of the year while South Africa, Madagascar and Zimbabwe will be voting in 2013. Unfortunately, this article cannot examine elections in each and every African State. The focus will then be on the Democratic Republic of Congo (DRC) with regard to the combined presidential and parliamentary elections held on 28 November 2011.

The DRC is the largest and most densely populated country located in the heart of the African continent. Surrounded by 11 other African continent, the DRC belongs to Central 
Africa, Eastern Africa and Southern Africa at the same time. Accordingly, it holds the membership of the Economic Community of Central African States (ECCAS), the Common Market of Eastern Africa (COMESA), and the Southern Africa Development Community (SADC) respectively. In 2005, after a political transition based on the interim constitution adopted by Congolese leaders from the government, armed and unarmed position as well as the civil society during the Inter-Congolese Dialogue (ICD) held in Sun City, South Africa, in order to end the conflict that broke out in August 1998 in the DRC, the Congolese people went to a referendum to adopt a new constitution. This constitution was adopted by referendum on 18-19 December 2005 and President Kabila promulgated it on 18 February 2006. ${ }^{12}$ This Constitution paved the way to the organisation of general elections in 2006. In November 2011, the Congolese people again went to elections.

Despite the controversy on their credibility, the DRC presidential and parliamentary elections of 28 November 2011 were largely ignored among academics and researchers. How were these elections organised? As compared to the 2006 elections, did the November 2011 elections constitute a step forward to democratic consolidation? Were they democratic, free and fair? Is there any lesson for the rest of the continent in relation to the organisation of democratic elections?

This article builds on the findings and conclusions we made in our previous contribution to a 2008 issue of Law, Democracy \& Development,${ }^{13}$ and strives to answer the above and other related questions. It first deals with the legislative framework that governed the November 2011 elections. It then focuses on the process that led to the holding of the elections, on these elections and their results prior to reflecting on their regularity or credibility. Finally, it stresses the irregularities, reflects on the reactions of the international community, including the United Nations, the European Union, the African Union, and sub-regional organisations such as SADC, ECCAS, COMESA, and ICGL vis-à-vis these elections.

\section{Legal framework related to elections in the DRC}

The 28 November 2011 elections were mainly based on the legal framework that governed the July 2006 elections. This framework was slightly amended to meet the challenges raised by the 28 November 2011 elections and adapt to the new political environment.

\subsection{The constitution}

In terms of its 2006 Constitution, the DRC is subdivided in 25 provinces, namely Bas-Uele, Bandundu, Bas-Congo, Equateur, Haut-Lomami, Haut-Katanga, Haut-Uele, Ituri, Kasai, Kasai Central, Kasai Oriental, Kongo Central, Kwango, Kwilu, Lomami, Lualaba, Mai-Ndombe, Maniema, Mongala, Nord-Kivu, Nord-Ubangi, Sankuru, Sud-Kivu, Sud-Ubangi, Tanganika, Tshopo, and Tshuapa. Kinshasa, which is the capital city and the headquarters of national institutions, has the status of a province. ${ }^{14}$ Pending the creation of these 25 provinces, the DRC consists of the City of Kinshasa and ten provinces, which are Bandundu, Bas-Congo, Equateur, Katanga, Kasai-Occidental, Kasai-Oriental, Maniema, Nord-Kivu, Province-Orientale, and Sud-Kivu. ${ }^{15}$ 
Each province is led by a provincial government that consists of a Governor, a Vice-Governor, and ten provincial ministers. ${ }^{16}$ The provincial legislative authority is vested in the Provincial Assembly. ${ }^{17}$ Each province is also divided into districts. 26 districts were established and were to transform into provinces after the expiration of a period of 36 months following the effective inauguration of the political institutions provided for by the Constitution. ${ }^{18}$ The provinces are divided into several decentralised territorial entities. ${ }^{19}$

The 2006 Constitution contains a number of provisions aimed at promoting democratic elections. ${ }^{20}$ The DRC is to be a democratic state based on the rule of law. ${ }^{21}$ Multipartyism is recognised and the opposition allowed. All Congolese citizens who enjoy their civil and political rights may create political parties or join those of their choice. Parties operate freely subject to the law, public order and good morale. ${ }^{22}$ They may receive public funds to finance their activities and electoral campaigns. ${ }^{23}$ The establishment of a single party in the Republic or in any part thereof is prohibited and considered an imprescriptible crime of high treason. ${ }^{24}$ This is in line with the AU Constitutive Act that outlaws any unconstitutional change of government. ${ }^{25}$

The DRC 2006 Constitution contains a unique provision that imposes on every Congolese citizen the duty to oppose any individual or group of individuals that seize power and rule the country in violation of the Constitution. ${ }^{26}$

Political opposition is also recognised and its status determined by an Act of Parliament. ${ }^{27}$ This Act was passed on 4 December 2007 and provides for the rights, duties, organisation and functioning of the political opposition. ${ }^{28}$

In terms of the DRC Constitution, the power belongs to the people who are sovereign and exercise their sovereignty directly through elections and referendum and indirectly by their representatives. An Act of Parliament provides for the organisation of the referendum and elections. ${ }^{29}$ Suffrage is universal, equal and by secret. All adult Congolese citizens who are older than 18 years of age and enjoy their civil and political rights are entitled to vote and to be elected. ${ }^{30}$ Exceptions concern the Congolese citizens who are in prisons or abroad. Inspired by human rights instruments such as the Universal Declaration of Human Rights (UDHR) and particularly the African Charter on Human and Peoples' Rights (ACHPR), the Constitution enshrines individual and collective rights, including the right to vote in regular, free and fair elections. ${ }^{31}$

As far as elections are concerned, the 2006 Constitution provides for the election of the president, ${ }^{32}$ the members of the National Assembly ${ }^{33}$ and the Senate ${ }^{34}$, which are the two houses of Parliament, ${ }^{35}$ the members of the Provincial Assemblies ${ }^{36}$ or provincial legislatures. The governors and vice-governors are also elected. ${ }^{37}$

The President, ${ }^{38}$ the members of the National Assembly, the Senate, the Provincial Assemblies, the Governors and Vice-Governors are elected for a five year term. ${ }^{39}$ The President can serve two consecutive terms only. ${ }^{40}$

The President, the members of the National Assembly and the Provincial Assemblies are directly elected by popular vote or universal suffrage while the Senators, Governors and Vice-Governors are elected by the members of the Provincial Assemblies.

The president and the members of the National Assembly represent the nation. Republic constitutes the constituency for the election of the president. The president is directly elected by the entire population legally entitled to vote. The members of the National Assembly and the Provincial Assemblies are also directly elected by the people in their different provinces that are therefore divided into constituencies in terms of the Electoral Act. These constituencies are the same as for the members of the National 
Assembly and those of the Provincial Assemblies. On the other hand, the senators represent the provinces. The number of the members of the National Assembly, the Senate, and the Provincial Assemblies depend on the number of registered voters in these provinces. Some provinces and constituencies have more members than others.

Elections are national, provincial, urban and local. The Constitution provides that an Electoral Act should be enacted by Parliament. ${ }^{41}$ The number of the Members of the National Assembly, the Senate, and the Provincial Assemblies as well as the number of the members of the legislatures of the decentralised territorial entities are determined by the Electoral Act. ${ }^{42}$ The Electoral Act deals with the registration of the voters, determines the constituencies, the conditions for eligibility, the time and duration of the electoral campaigns, the electoral operations to be conducted from the time of voting to the announcement of the results as well as the competence of the EIC and the Constitutional Court. $^{43}$

The DRC 2006 Constitution was amended on 20 January $2011 .^{44}$ The 2011 constitutional amendment inter alia suppressed the run-off presidential election and provided for the election of the president by a simple majority vote, ${ }^{45}$ and delayed the process of the transformation of the districts into fully-fleshed provinces. ${ }^{46}$

It also provided for the dissolution of a provincial assembly and for the dismissal of a governor of a province by the president. ${ }^{47}$

The DRC Constitution provides for a number of institutions supporting democracy. These institutions are expected to play an important in ensuring free and fair elections. These include the Electoral Independent Commission (EIC) ${ }^{48}$ and the High Authority of the Media and Communication. ${ }^{49}$ The EIC and High Commission for the Media and Communication are governed by organic laws enacted by Parliament which provide for their organisation and functioning. ${ }^{50}$

The EIC is an independent and non-partisan institution entrusted with the mandate to manage the electoral process. Voters' and candidates' registration, the appointment of electoral officers, the timing up of the election and electoral campaigns, and the declaration of the provisional results are part of the EIC mandate.

The High Authority for the Media and Communication is to ensure that all parties and candidates enjoy equal access to the media, especially state media, and the media contribute to free and fair elections as well as democratic consolidation.

However, the most important institution in ensuring democratic elections is the judiciary, particularly the Constitutional Court. The DRC 2006 Constitution provides that the Constitutional Court is composed of 9 judges. Three judges are appointed by the president, three by Parliament and the remaining three by the High Council of the Magistracy. ${ }^{51}$

The Constitutional Court deals with all constitutional matters. ${ }^{52}$ It also deals will electoral matters and electoral disputes related to presidential and parliamentary elections. ${ }^{53}$ Its decisions are final and binding. ${ }^{54}$ The Supreme Court of Justice exercises the competence of the Constitutional Court pending its establishment. ${ }^{55}$

Despite the adoption by Parliament of an organic law governing the organisation and the functioning of the Constitutional Court, the latter has not been established as yet. The president refrained to promulgate the new Act as he seemed happy with the composition of the Supreme Court of Justice, at least until the settlement of the disputes related to the 2011 elections. 


\subsection{Electoral laws and systems}

The 28 November 2011 elections were governed by an Electoral Act passed by Parliament. ${ }^{56}$ This Act was an amendment of the Electoral Act that governed the 2006 Elections. $^{57}$

In compliance of the 2006 Constitution as amended in January 2011, the amended Electoral Act provided for the election of the president by popular vote in a single round and for minor changes in relation to the elections of the Members of Parliament, the Provincial Assemblies, Governors and Vice-Governors. The two electoral systems provided for by the 2006 Electoral Act were the majority system and the proportional representation system. ${ }^{58}$ All these systems were based on lists submitted by independent candidates or parties. The 2011 Electoral Act retained the majority system for the presidential election and the election of the Governors and Vice-Governors ${ }^{59}$ while maintaining proportional representation ${ }^{60}$ for the election of the members of the national, provincial, urban and local legislatures. The proportional representation was a complicated system.

Suffrage was uninominal in each single seat constituency. Each list contained one name only. The candidate on the list that obtained the majority vote was declared elected. However, suffrage was plurinominal in multiple-seat constituencies. There were several lists. The Electoral list determined the electoral quotient.

Each voter was entitled to cast one vote for a candidate of his or her choice on the list which contained names corresponding to the total number of seats in the constituency. The total number of votes of a list was equal to the number of votes obtained by each candidate on that list. The seats were distributed among the lists on the basis of the total number of votes obtained by the candidates on those lists. The candidate on the list of a party or the independent candidate that obtained most votes after division of the list total number of votes by the electoral quotient was elected. The remaining seats were distributed among parties according to the highest-rest rule that applied. With regard to the electoral systems, there was no change between the 2006 Electoral Act and the Electoral Act that governed the DRC 2011 elections.

The DRC Constitution and Electoral Act as amended in 2011, the Act of Parliament establishing the NIEC and the High Authority of the Media and Communication and the decisions and guidelines set up by these institutions supporting democracy constituted the legal framework governing the 28 November 2011 elections. It is against this legal and institutional background that these elections were to be conducted and their credibility assessed to find out whether they were democratic, free and fair or they were not.

\section{DRC 28 November 2011 elections}

\subsection{Steps towards the 28 November 2011 elections}

A number of steps were taken in preparation for the 28 November 2011 elections. The first step was the Act of Parliament related to the NIEC, its organisation and functioning. The president assented to this Act on 28 July 2010. ${ }^{61}$ This Act took a long time to be adopted by Parliament as both the majority and the opposition disagreed on the composition of the Bureau of the NIEC. 
The second step was the constitutional amendment of 20 January 2011 that provided for the election of the president by a simple majority of the votes. ${ }^{62}$ The third step was the inauguration of the NIEC by a presidential decree signed on 3 February $2011 .^{63}$ The majority in Parliament rejected Senator Jacques Djoli who was among the three people nominated by the opposition to serve on the Bureau. Senator Djoli was a member of the MLC (Mouvement de Libération du Congo), which was the leading opposition party. The majority rejected his nomination, as they thought he would be an obstacle to the reelection of their leader, President Joseph Kabila. On the other hand, the opposition rejected the nomination of Reverend Daniel Ngoy Mulunda who was likely to lead the NIEC. They alleged that he originated from the same province (Katanga) as the incumbent president Joseph Kabila who was running for a second term. They further alleged that he was a founding and remained an influential member of the presidential party, namely the PPRD (Parti pour le Progrès, la Reconstruction et la Démocratie), the leading party of the ruling majority. For the opposition, elections would be rigged in favour of the president and the majority and the NIEC would lose any autonomy and impartiality if Reverend Mulunda was to preside over its Bureau. Finally, both sides agreed to compromise by adopting their respective lists and the Bureau of the NIEC could be inaugurated and start its work after weeks of stalemate. Once inaugurated, the Bureau of the NIEC adopted its rules of proceedings which were declared consistent with the Constitution by the Supreme Court of Justice on 25 February $2011 .{ }^{64}$ On 30 April 2011, the Bureau of the NIEC published the electoral timetable for 2011-2013. ${ }^{65}$

The 2006 Electoral Act related to the organisation of presidential, parliamentary, provincial, urban, municipal and local elections was amended on 25 June $2011 .^{66}$ In line with this amended Electoral Act, Parliament adopted another Act distributing seats per electoral constituency for the parliamentary and provincial elections. This Act was promulgated on 17 August $2011 .^{67}$

Since the presidential election and the election of the members of the National Assembly had to take place in 2011 prior to that of the members of the Provincial Assemblies, the Bureau of the NIEC went on to receive the nominations of the candidates to these two elections. It published the provisional lists of the candidates to the presidential election ${ }^{68}$ and to the election of the members of the National Assembly on and 15 September 2011 respectively. ${ }^{69}$

Following confirmation by the Supreme Court of Justice, the Bureau of the NIEC published the final lists of the candidates for the presidential election ${ }^{70}$ and the election of National Deputies. ${ }^{71}$ The Bureau of the NIEC could then appoint the members of the personnel of the NIEC at all levels, order the electoral material, and supervise its dispatching to the voting stations in the country. The Electoral Act provided for a 30-day electoral campaign that ended a day before the election on 28 November 2011. The period of the campaign was the same for the presidential election as for the election of National Deputies, which were the only elections held in November 2011 since the election of the members of the Senate, Governors and Vice-Governors, the Provincial Deputies and urban, municipal and local elections were to be take place later according to the timetable established by the Bureau of the NIEC.

An interesting development was that shortly before the beginning of the electoral campaign, President Joseph Kabila appointed the judges of the Constitutional Court without consulting with the judicial commission. These judges were sworn in later by the president during the electoral campaign. 


\subsection{Organisation and results of the DRC 28 November 2011 elections}

As provided by the Bureau of the NIEC, although they were to be held on the same day, the results of the presidential election were to be announced before of the election of the National Deputies.

\subsubsection{Presidential elections}

As stressed earlier, 11 candidates were registered for the presidential election. Attempts by the opposition to rally around a single presidential candidate against the incumbent president failed.

Table 1 List of presidential candidates ${ }^{72}$

\begin{tabular}{|c|c|c|}
\hline Candidate no. & Candidates' names & Political affiliation \\
\hline 01 & Andeka Djamba Jean & $\begin{array}{c}\text { ANCC (Alliance des Nationalistes Croyants } \\
\text { Congolais) }\end{array}$ \\
\hline 02 & Bombole Intole Adam & Independent \\
\hline 03 & Kabila Joseph & $\begin{array}{c}\text { Independent (But Leader of Presidential } \\
\text { Majority) }\end{array}$ \\
\hline 04 & $\begin{array}{l}\text { Kakese Malela François } \\
\text { Nicefort }\end{array}$ & $\begin{array}{l}\text { URDC (Union pour le Réveil et le } \\
\text { Développement du Congo) }\end{array}$ \\
\hline 05 & $\begin{array}{l}\text { Kamerhe Lwa Kanyinginyi } \\
\text { Vital }\end{array}$ & UNC (Union Nationale Congolaise) \\
\hline 06 & Kashala Lukumwena Oscar & URC (Union pour la Reconstruction du Congo) \\
\hline 07 & Kengo wa Dondo Léon & UFC (Union des Forces du Changement) \\
\hline 08 & Mbusa Nyamuisi Antipas & Independent \\
\hline 09 & $\begin{array}{l}\text { Mobutu Nzanga Ngbagawe } \\
\text { François Joseph }\end{array}$ & UDEMO (Union des Démocrates Mobutistes) \\
\hline 10 & Mukendi Kamana Josué Alex & Independent \\
\hline 11 & $\begin{array}{l}\text { Tshisekedi wa Mulumba } \\
\text { Etienne }\end{array}$ & $\begin{array}{c}\text { UDPS/Tshisekedi (Union pour la Démocratie et } \\
\text { le Progrès Social/Tshisekedi) }\end{array}$ \\
\hline
\end{tabular}

A day after the election, many opposition leaders and independent observers announced the victory of opposition leader Etienne Tshisekedi. The contestation had begun. Despite several reports on massive electoral irregularities in many areas, the NIEC provisionally announced the results of the 28 November 2011 presidential election on Friday 9 December 2011. Without any surprise, the incumbent President Joseph Kabila was declared the winner with $48,95 \%$.

He was followed by opposition candidates Etienne Tshisekedi (32, 33\%), Vital Kamerhe $(7,74 \%)$, and Léon Kengo wa Dondo (4, 95\%). The remaining candidates scored less than $2 \%$.

The decision of the Bureau of the NIEC was referred to the Constitutional Court for confirmation and contesting candidates were urged to lodge their complaints with the highest Court. On the basis of the reports from the witnesses of his party and several independent observers, including those of the Catholic Church, Etienne Tshisekedi rejected the results announced by the Bureau of the NIEC and declared himself president. Accordingly, he declined to challenge them in the Constitutional Court which the 
opposition already accused of lacking independence and being in the service of candidate Joseph Kabila. The decision of the Bureau of the NIEC was referred to the Constitutional Court for confirmation and contesting candidates were urged to lodge their complaints with the highest Court. On the basis of the reports from the witnesses of his party and several independent observers, including those of the Catholic Church, Etienne Tshisekedi rejected the results announced by the Bureau of the NIEC and declared himself president. Accordingly, he declined to challenge them in the Constitutional Court which the opposition already accused of lacking independence and being in the service of candidate Joseph Kabila. The only legal challenge came from Vital Kamerhe (Candidate no. 5) who also rejected Joseph Kabila's election and congratulated Etienne Tshisekedi on his victory.

Table 2 Provisional results of the presidential election ${ }^{73}$

\begin{tabular}{llcc}
\hline No. & Candidates' names & Votes & Percentage \\
\hline 01 & Kabila Joseph & 8.880 .944 & $48,95 \%$ \\
02 & Tshisekedi wa Mulumba Etienne & 5.864 .775 & $32,33 \%$ \\
03 & Kamerhe Lwa Kanyinginyi Vital & 1.403 .372 & $7,74 \%$ \\
04 & Kengo wa Dondo Léon & 898.362 & $4,95 \%$ \\
05 & Mbusa Nyamuisi Antipas & 311.787 & $1,72 \%$ \\
06 & Mobutu Nzanga Ngbagawe François Joseph & 285.273 & $1,57 \%$ \\
07 & Andeka Djamba Jean & 128.820 & $0,71 \%$ \\
08 & Bombole Intole Adam & 126.623 & $0,70 \%$ \\
09 & Kakese Malela François Nicefort & 92.737 & $0,51 \%$ \\
10 & Mukendi Kamana Josué Alex & 78.151 & $0,43 \%$ \\
11 & Kashala Lukumwena Oscar & 72.260 & $0,40 \%$ \\
\hline
\end{tabular}

According to the Electoral Act, the challenge was brought by Mr Kamerhe's party, namely the UNC, on Monday 12 December $2011 .{ }^{74}$ Without any surprise, the Court unanimously and unreservedly dismissed the UNC's application on 16 December $2011 .^{75}$ The Court went on to confirm the decision of the Bureau of the NIEC. It proclaimed Joseph Kabila the winner of the 28 November 2011 presidential election before receiving his oath of office as DRC president on 19 December 2012. A week later, Etienne Tshisekedi addressed the people from his residence in Kinshasa-Limete for his own official swearing in as 'DRC legitimate president'. Since then, the DRC has two presidents, namely Joseph Kabila, the official and effective president proclaimed by the NIEC, confirmed by the Constitutional Court and recognised by the international community on the one hand, and Etienne Tshisekedi, the self-proclaimed 'elected' and 'legitimate' president who has been denied imperium and recognition by the international community.

\subsubsection{Elections of the members of the national assembly}

18,478 candidates (2,244 female candidates only) participated in the elections of the National Assembly. ${ }^{76}$ Most candidates were nominated by the 423 political parties that were then registered in the DRC.

Accusations of vote-rigging, corruption of the members of the NIEC, subordination of witnesses, falsifications of results, violence, destruction of ballot papers in areas 
favourable to the opposition and their multiplication in those favourable to incumbent President Joseph Kabila, his party and coalition that were aired before the announcement of the results of the presidential election intensified and aggravated while the nation awaited the results of the election of the Members of the National Assembly. These allegations of frauds were confirmed by the overwhelming majority of independent observers, including those from the Carter Foundation and the European Union (EU). They contributed to discrediting further the electoral process and the NIEC. At some stage, President Kabila himself acknowledged that a number of irregularities had been committed that could not, however, impact on his victory. The situation worsened when the NIEC suspended the operations of vote counting and delayed the announcement of the results.

A team of American and British independent observers was invited to help the NIEC retain some credibility of the elections, especially the parliamentary elections as the results were still pending. They were prevented from working on their arrival and quickly left the country. The NIEC denied inviting them as they feared that their findings could reinforce or corroborate the accusations of frauds during the presidential election which was held the same day as the parliamentary elections. This prompted (self-proclaimed) President Tshisekedi to nullify the parliamentary elections.

Table 3 List of parties/political groupings with more than five seats during the election of National Deputies on 28 November 2012 in the DRC

\begin{tabular}{lllc}
\hline No. & Acronyms & Names & $\begin{array}{c}\text { Number of } \\
\text { seats }\end{array}$ \\
\hline 01 & PPRD & Parti pour le Progrès, la Reconstruction et la Démocratie & 62 \\
02 & UDPS & Union pour la Démocratie et le Progrès Social / Tshisekedi & 41 \\
03 & PPPD & Parti du Peuple pour la Paix et la Démocratie & 29 \\
04 & MSR & Mouvement Social pour le Renouveau & 27 \\
05 & MLC & Mouvement de Libération du Congo & 22 \\
06 & PALU & Parti Lumumbiste Unifié & 19 \\
07 & UNC & Union Nationale Congolaise & 17 \\
08 & ARC & Alliance pour le Renouveau du Congo & 16 \\
09 & AFDC & Alliance des Forces Démocratiques du Congo & 15 \\
10 & ECT & Eveil de la Conscience pour le Travail et le Développement & 11 \\
11 & RRC & Rassemblement pour la Reconstruction du Congo & 11 \\
12 & MIP & Mouvement pour l'Intégrité du Peuple & 10 \\
13 & PDC & Parti Démocrate Chrétien & 07 \\
14 & UDECO & Union pour le Développement du Congo & 07 \\
15 & RCD/K-ML & Rassemblement Congolais pour la & 06 \\
& & Démocratie/Kisangani-Mouvement de Libération & \\
16 & UNADEF & Union Nationale des Démocrates Fédéralistes & 06 \\
17 & UNAFEC & Union des Nationalistes Fédéralistes du Congo & 06 \\
18 & CCU & Convention des Congolais Unis & 05 \\
19 & CPR & Convention des Progressistes pour la République & 05 \\
20 & NAD & Nouvelle Alliance des Démocrates & 05 \\
21 & UCP & Union des Congolais pour le Progrès & 05 \\
\hline & & & \\
\hline
\end{tabular}


Nevertheless, the Bureau of the NIEC went on to announce the provisional results. The Bureau of the NIEC officially announced the results on 26 January $2012^{77}$ and 1 st February 2012 respectively, except for six constituencies, namely Demba, Ikela, Kiri, Kole, Masisi and Kole where elections were nullified. ${ }^{78}$

According to the NIEC, PPRD and other parties members of the MP obtained the two-thirds majority. In terms of the number of seats, PPRD was followed by UDPS. Twenty-one parties or political groupings won at least five seats in the National Assembly.

Twenty-seven parties or political groupings won from two to four seats while 42 parties $^{79}$ have a single member in the National Assembly and 17 are independent.

Table 4 List of parties/political groupings with between two and four seats during the election of National Deputies on 28 November 2012 in the DRC

\begin{tabular}{|c|c|c|c|}
\hline No. & Acronyms & Names & $\begin{array}{l}\text { Number of } \\
\text { seats }\end{array}$ \\
\hline 01 & ATD & Alliance des Travaillistes Congolais pour le Développement & 04 \\
\hline 02 & $\mathrm{CDC}$ & Convention des Démocrates Chrétiens & 04 \\
\hline 03 & COFEDEC & $\begin{array}{l}\text { Démocratie Chrétienne Fédéraliste - Convention des } \\
\text { Fédéralistes pour la Démocratie Chrétienne }\end{array}$ & 04 \\
\hline 04 & CRD & Convention pour la République et la Démocratie & 04 \\
\hline 05 & MCR & Mouvement Congolais pour la Renaissance & 04 \\
\hline 06 & UDECF & Union des Démocrates Chrétiens Fédéralistes & 04 \\
\hline 07 & $\mathrm{DCF} / \mathrm{N}$ & Démocratie Chrétienne Fédéraliste/Nyamwisi & 03 \\
\hline 08 & ECIDé & Engagement pour la Citoyenneté et le Développement & 03 \\
\hline 09 & PANADER & Parti National pour la Démocratie et la République & 03 \\
\hline 10 & PCD & Parti Congolais pour le Développement & 03 \\
\hline 11 & SET & Soutien à Etienne Tshisekedi & 03 \\
\hline 12 & UFC & Union des Forces du Changement & 03 \\
\hline 13 & BCUP & Bâtir un Congo Uni et Prospère & 02 \\
\hline 14 & CAAC & Congrès des Alliés pour l'Action au Congo & 02 \\
\hline 15 & $\mathrm{CNC}$ & Congrès National Congolais & 02 \\
\hline 16 & CONGO-PAX & Parti pour la Paix au Congo & 02 \\
\hline 17 & $\mathrm{FC}$ & Fondation du Congo & 02 \\
\hline 18 & GSCO & Génération pour la Solidarité et le Développement du Congo & 02 \\
\hline 19 & LDIC & Ligue pour la Défense des Intérêts des Citoyens & 02 \\
\hline 20 & MSDD & $\begin{array}{l}\text { Mouvement de Solidarité pour la Démocratie et le } \\
\text { Développement }\end{array}$ & 02 \\
\hline 21 & PR & Parti Réformateur & 02 \\
\hline 22 & RDP & Regroupement des Démocrates pour le Progrès & 02 \\
\hline 23 & RECO & Parti pour la Renaissance du Congo & 02 \\
\hline 24 & SCODE & Solidarité Congolaise pour la Démocratie & 02 \\
\hline 25 & SODENA & Solidarité pour le Développement National & 02 \\
\hline 26 & UDEMO & Union des Démocrates Mobutistes & 02 \\
\hline 27 & UPC & Union des Patriotes Congolais & 02 \\
\hline
\end{tabular}


The provisional results were referred to the Supreme Court of Justice that received around 500 petitions mainly from the MP. In its judgment on 24 April 2012, the Court confirmed these results except for 32 candidates whose election was nullified. ${ }^{80}$

The court also ordered the Bureau of the NIEC to announce the results in the six constituencies where the elections had been nullified. According to the Constitution that provides that the decisions of the Supreme Court of Justice are final and binding, ${ }^{81}$ the Bureau of the NIEC announced the provisional results of the election of National Deputies in these constituencies. ${ }^{82}$ The Court received several petitions related to these results but finally confirmed the results in early September 2012. This brought to the end the electoral disputes related to the election of the National Deputies of 28 November 2011 in the DRC.

\section{Credibility of the DRC 28 November 2011 elections}

The credibility of the 28 November 2011 elections can be assessed in the light of the comments from the Congolese political leaders, the findings of many independent observers, and the attitude of the NIEC and the Supreme Court of Justice. The main cases of non-compliance will then be highlighted as well as international, regional and sub-regional responses to those irregularities.

\subsection{Congolese leaders and the 28 November 2011 elections}

The winners, President Joseph Kabila, his party (PPRD) and his coalition (MP) accepted the results of these elections while the opponents, who were the losers, rejected them as not being free and fair. However, both parties agreed that these elections were fraudulent.

President Kabila was among the first to concede that there were irregularities but he was quick to add that they were not of such magnitude as to render the elections noncredible, especially the presidential election.

More recently, responding to the press, the president announced that a reform of the NIEC was in the pipeline since a bill had already been tabled in the National Assembly.

Among the political leaders and parties supporting the president, there were mutual accusations that ended up in the Constitutional Court which had to deal with the majority of disputes opposing the members of the MP. They too admitted that the 28 November 2011 elections were not free and fair and failed to comply with norms and principles governing democratic elections.

\subsection{Independent observers and the 28 November 2011 elections}

Even before the proclamation of the results by the NIEC and their contestation by opposition presidential candidates, international and national independent observers had started ringing the bell about the massive irregularities that affected the credibility of the 28 November 2011 elections. Among these observers were the delegates from the Carter Foundation, the EU, the powerful Catholic Church, which is present in the entire country and had deployed several thousand observers, and Congolese non-governmental organisations (NGOs), especially the four that formed the National Observation Mission, namely RENOSEC (Reseau National pour l'Observation et la Surveillance des Elections au Congo), ROC (Reseau d'Observation des Confessions Religieuses), CAFCO (Cadre 
Permanent de Concertation de la femme Congolaise) and CNJ (Conseil National de la Jeunesse).

The National Observation Mission deployed 12,688 observers in 9,074 voting stations across the country. ${ }^{83}$ ROC deployed an additional 17.000 observers. NOM published four documents related to these elections. These included a statement on 7 November 2011 assessing the pre-electoral situation, a report on the political environment during the presidential and parliamentary elections 27 November 2011, an interim report on 16 December 2011, and a final report on 15 January 2011.

The overwhelming majority of observers concurred that the electoral process managed by the NIEC was not credible and by 28 November 2011 elections were marred with numerous irregularities and could hardly be considered free and fair by international and domestic standards.

\subsection{The NIEC and the 28 November 2011 elections}

Despite all the reports pointing on the irregularities that spoiled the presidential and the parliamentary elections, the NIEC went on to announce the results.

Responding to a question from a reporter of a French Radio, Radio France International (RFI) a few days after the announcement of the provisional results of the presidential election, NIEC Deputy-President Jacques Djoli came close to admitting these irregularities when he confessed that he was forced to agree with his colleagues within the Bureau to avoid a looming political crisis. Many people were disappointed that this constitutional law professor and opponent who had given them the image of a man of integrity during his term as a senator finally endorsed fraudulent electoral results and believed what was publicly rumoured he and his colleagues had taken millions of US dollars as a bribe to proclaim the incumbent president the winner of the election. They found his statement irresponsible for a man of his calibre and he himself did not repeat it.

Another moment when the Bureau indirectly acknowledged its wrongdoing in running the elections was during the presentation of their annual report to the National Assembly on 14 June 2012. Responding to critics on behalf of the Bureau, Deputy-President Djoli held that the quality of the Congolese leaders and politics was reflected in the November 2011 elections. He added that no elections were perfect and the NIEC was not the only institution to be blamed for failure. The National Assembly was also responsible for passing the Electoral Act and inaugurating the NIEC late and for not providing them with the necessary resources to succeed. This was typical of political leaders in Africa in general and in the DRC in particular where mistakes are hardly acknowledged but generally justified.

\subsection{The constitutional court and the 28 November 2011 elections}

More than 500 disputes were brought before the Constitutional Court in relation to the parliamentary elections. 32 members of the National Assembly already proclaimed by the NIEC were invalidated. This fuelled criticism already levelled at the NIEC. However, the Court did not end there and added to the irregularities of the 28 November 2011 elections by proclaiming some candidates of the presidential coalition who were not retained by the NIEC and who did not even appeal to the Court. After the NIEC, the Court was also blamed for corruption and unconfirmed reports alleged that the Court had been ordered to dismiss as many applications from the opposition as possible and to ensure that the 
president get the majority in the National Assembly in order for his government to easily apply his programme of action.

The Bureau of the NIEC also criticised the Supreme Court for proclaiming the candidates in constituencies where they had proposed the nullification of the election due to several irregularities. This resulted in a conflict between the two institutions and confirmed that the 28 November 2011 elections were not democratic. The NIEC had nevertheless to bow down before the Court on the ground that its decisions are final and binding. The attitude of the DRC Supreme Court in this case and many others gives rise to the question whether and why the rule of law also requires respect for unjust but final decisions made by the highest court in the land.

\subsection{Cases of non-compliance with norms governing democratic elections}

Numerous cases of irregularities of the DRC 28 November 2011 elections and noncompliance with international and constitutional norms and principles governing democratic elections were reported by political leaders, parties' witnesses and independent observers. These irregularities included the following:

- Lack of independence of the highest court as well as the NIEC despite it being named 'independent'. These institutions remained subject to the incumbent president and to the ruling party and majority. The majority of the members of the NIEC Bureau were nominated by the president who also appointed the judges of the Supreme Court among his supporters in the judiciary, without a proper consultation with the Judicial Commission as provided by the constitution.

- This appointment also took place in tempore suspecto, just before the electoral campaign, and they were sworn in by a president who was not longer entitled to do it, as he was a presidential candidate among others. Such judges were aware that they owed him. Therefore, they were accountable to the president and to the ruling majority. They could not afford to 'betray' them and the only way to pay back was to announce their victory.

- Violation of Article 6 and Article 8 of the Electoral Act by the NIEC for failing to publish the lists of registered voters by province and by constituency at least 30 days before the beginning of the electoral campaign. In each voting station, the lists of registered voters, including their names, places and dates of birth, sex, addresses of domiciles or habitual residences had to be published at least 30 days before the election day.

- Intimidation of voters and electoral officers as well as destruction of electoral material by some candidates and their parties.

- Late opening of the voting stations on the election day.

- Unavailability of some voting stations where voters were expected to cast their votes and unannounced change of venues of some voting stations. As a result, many registered voters were disoriented and could not cast their votes despite the fact that Article 47 of the Electoral Act provided that the NIEC should publish the list of voting stations and their addresses 30 days before the election. This did not allow candidates and parties to accredit their witnesses in time. 
- Insufficient ballot papers as compared to the number of registered voters in many voting stations favourable to opposition candidates, in violation of Article 56 of the Electoral Act. However, the number of ballot papers largely exceeded that of registered voters in areas favourable to presidential candidate no. 3 (Joseph Kabila).

- Possession of unregistered ballot papers by some candidates and unauthorised persons. These papers were later introduced in the system and benefited some candidates and their parties, especially those of the ruling coalition.

- Thousands of ballot papers were already earmarked in favour of presidential candidate no. 3 and some candidates of his party or majority in a number of voting stations.

- In some areas of his province of origin (Katanga), presidential candidate Joseph Kabila obtained $100 \%$ as if no registered voter had been sick, dead or unavailable while the 10 remaining candidates scored $0 \%$. The Supreme Court ${ }^{84}$ dismissed Vital Kamerhe's complaint on the ground that the Constitution did not prevent any candidate from scoring $100 \%$.

- Some candidates were allowed to campaign after the deadline and around the voting stations, in violation of the Electoral Act.

- The minutes of vote counting in some areas were not signed by competent electoral officers and by the witnesses of the candidates or parties, in violation of Article 38 of the Electoral Act.

- Witnesses of candidates and parties were prevented from entering some voting and counting stations. The aim was to facilitate frauds. The absence of witnesses was not a ground for nullification of the vote, except if it was intentional, which unfortunately seemed to the case in many voting stations and counting centres.

- Falsification of ballot papers and election results in many areas.

- Reception of the parcels containing the ballot papers and the results of the voting in some counting stations several days after the election and manipulation or falsification of the results during their transfer, in violation of the Electoral Act.

- Non-publication of the results in the voting stations.

- Lack of independence and professionalism of public servants in the administration and security services (army and police) who felt duty bound to work for the reelection of the outgoing president, the ruling party or majority.

- Lack of independence and impartiality of the public media, which campaigned for the outgoing president, his party and coalition while closing their doors to the opposition, in violation of the Constitution and the Electoral Act.

- Utilisation of state material, financial resources and state personnel in the campaign of the outgoing president, the candidates of his party or coalition, also in violation of the Constitution and Article 36 of the Electoral Act.

- This could lead to the invalidation of a candidate or a party list. Instead of enforcing this provision and invalidating the lists of the ruling party or majority, the NIEC rather decided to advise them without even obtaining their compliance. 
- Posting of campaign messages on public buildings, in violation of Article 30 of the Electoral Act.

- Destruction of many ballot papers, especially in areas suspected of favouring the opposition.

- Discordance between the results which were published by the NIEC and confirmed by the Constitutional Court with those published in the voting stations in order to favour of the outgoing president, the ruling party or coalition and their candidates.

- Presence in the voting stations of non-authorised persons such as local heads of the administration, and the members of the security services.

- Corruption of electoral officers or their collusion with some candidates, particularly those of the ruling party or coalition in many areas.

Against this background, the DRC 28 November 2011 elections did not comply with constitutional provisions and principles governing democratic elections.

\subsection{International, regional and sub-regional responses to DRC's non-compliance with norms, principles, standards and guidelines governing democratic elections}

A number of norms and principles were adopted at the international, regional and subregional levels in order to promote democratic elections. However, how did the international community, the AU, and regional bodies such as SADC and ECCAS react to the irregularities that affected the 28 November 2011 elections?

After a false moment of suspense, the international community led by some Western 'democratic' leaders and governments rather welcomed the results and congratulated President Kabila and his government on successful and exemplary elections, disappointing millions of democrats worldwide and denying themselves any authority to give lessons on democratic elections.

The first response was expected to come from the UN Mission for the DRC, MONUSCO, which deployed around 20000 blue helmets in the country, the largest UN contingent in Africa since the Cold War.

The UN declined from playing a crucial role in preventing and combatting frauds. The Security Council did not even bother to listen to opposition leaders who wanted MONUSCO to be mandated to authenticate the results published by the NIEC, as this happened with the UN Mission in Cote d'Ivoire. President Kabila was not Laurent Gbagbo and there was no Security Council permanent member like France to push for such an extended mandate of MONUSCO. President Kabila had also learnt from Gbagbo's experience that this could amount to political suicide with possible deferment to the International Criminal Court (ICC). He therefore opposed and succeeded in keeping MONUSCO out with the assistance of all UN member states represented in the Security Council.

Despite the fact that they were not represented at the highest level during his inauguration, the world major powers were not interested in having President Kabila out as a result of the presidential election and in getting him replaced by some nationalist leader who could not preserve their interests. The Belgian government was the first Western government to visit the DRC and to congratulate President Kabila on his 
re-election. China, which had concluded lucrative deals with the DRC government, did not need to wait as it was among the first countries to be interested in the continuation of the Kabila regime.

On the other hand, the US under the Obama administration did not take long to forget about the reports of independent observers, including those from the Carter Foundation, and pledged to reinforce its cooperation with his government. French President François Hollande kept the Congolese people in an agonising feeling of suspense. In August 2012, he finally announced his decision to support President Kabila by participating in the 14th Summit of Francophone countries to be hosted by the DRC in October 2012. He therefore proved wrong most Congolese people in the opposition who had predicted that the French president would boycott the summit because the DRC failed to comply with norms and principles governing democratic elections. Former French President General de Gaulle is reported to have once said that states had no friends but interests.

In a globalised world where the French language was losing to English and other major foreign languages, it was naïve to believe that the French president would not participate in the summit aimed at preserving or reinforcing the leadership of his country that also required the promotion of French.

The scene was then set for the UN, the EU, and the rest of the international community to recognise President Kabila's re-election despite the fact that the DRC ailed to meet international and domestic norms, principles, standards and guidelines governing democratic elections. The observers of the Carter Foundation and the EU had prepared the ground and left the door open to such a worldwide recognition when they held that notwithstanding their irregularities, there was nothing suggesting that there could be change in the results giving Joseph Kabila the winner of the presidential election.

As for the observers of the AU and sub-regional organisations such as SADC, ECCAS, COMESA, and ICGL (International Conference on the Great Lakes) concluded that the 28 November 2011 elections were globally free and fair. Accordingly, African leaders congratulated President Kabila and the DRC on such successful elections. The opposite could be surprising from those African organisations that are still dominated by authoritarian leaders who do not really believe in democratic elections while the few democratically elected ones keep quiet and tend to compromise. Yet, democracy cannot prosper in Africa if the leaders of the international community, the governments of some key Western states, the $\mathrm{EU}$, the $\mathrm{AU}$, and African sub-regional organisations remain indifferent to African states' non-compliance with international and domestic norms and principles aimed at promoting democratic elections.

\section{Conclusions}

This paper focussed on the combined presidential and parliamentary elections held on 28 November 2011 in the DRC.

The country did not comply with international and regional norms as well as its own constitutional and legal provisions and principles governing democratic elections. It results from the decisions of the Supreme Court of Justice and the NIEC as well as from the findings and comments of several independent observers and the Congolese leaders themselves that these elections were marred with irregularities. They were not credible and failed to qualify as democratic, free and fair despite their approval by Western leaders, the EU and African organisations such as the AU, COMESA, ECCAS, and 
SADC to which the DRC belongs. The DRC 28 November 2011 elections ended up creating new political problems or aggravating the pre-existing ones rather than resolving them. The problem of legitimacy that the 2006 elections tended to resolve was back as Etienne Tshisekedi proclaimed himself the 'legitimate' president of the DRC and nullified the 28 November 2011 parliamentary elections. Other opposition leaders contested the results of the election. The political crisis continues with its negative consequences and ' $M$ 23', a rebellion movement launched in Eastern Congo with backing from Rwanda which is accused of invading the RDC, added to its claims the 'truth of the vote' supposedly rigged by President Kabila and his coalition.

One of the problems raised by the DRC 28 November 2011 elections is whether elections still matter and why people should continue to bother participating in a game which seems to be won in advance by the incumbent president and the ruling party or coalition. Despite this, a number of useful lessons can be learnt from these elections in order to promote and consolidate democracy through the organisation of free and fair elections in Africa.

First, democratic elections are subject to the rule of law and not to the law of the rulers. The organisation of free and fair elections requires the state to comply with general and impartial norms and principles.

Second, democratic elections cannot take place in a context where corruption is rampant in the administration, the public media, the army, the police, and other security services and where these institutions lack autonomy and tend to operate as sections of the ruling party or majority and remain subject to the incumbent leader and inimical to the opposition. The latter cannot feel secured and abide by the results when demanding democratic change amounts to fighting the state and all its institutions and not just contesting the ruling party or the incumbent leader.

Third, two institutions are critical for democratic elections. These are the Electoral Commission and the Constitutional (Supreme) Court. Both should be autonomous, independent, impartial and above parties' politics. Public media should also remain 'public', and equally accessible to all the candidates and parties. Arguably, there is no way elections can be democratic, free and fair when the Electoral Commission and the highest court in the land are highly politicised and lack independence vis-à-vis the incumbent president and the ruling party or coalition that tend to use them in order to retain power. The privatisation of the public media also constitutes a serious violation of the norms and principles governing democratic elections.

Four, elections cannot be democratic when the parties are not on an equal footing. The rules of the game are violated when the incumbent or outgoing president and the ruling party or coalition cling to power and tend to confiscate public material, financial and human resources to this end.

Five, foreign democratic governments, the $\mathrm{EU}$, the $\mathrm{AU}$ and sub-regional organisations such as ECCAS, ECOWAS, COMESA, SADC, and ICGL may play an important role in ensuring that African states comply with norms and principles governing democratic elections. Unfortunately, they contributed to undermining them by holding that the DRC 28 November 2011 elections were free and fair. Except for Cote d'Ivoire and Zimbabwe probably due to the influence of former colonial powers (France and Britain) who were unhappy with incumbent leaders, no election held in an African country has been declared undemocratic by the EU and Western democratic governments. On the other hand, electoral observation missions from the AU and African sub-regional organisations have always ended up with the same old story or recorded 
message that is music to those African leaders who have specialised in vote-rigging. All of us have memorised the verses and chorus of the favourite song of these special choirs: 'apart from some minor irregularities, elections have been free and fair'. On the basis of these 'songs' and even without awaiting to listen to their singers, African leaders are quick to congratulate their peers on their re-election as the old 'club' mentality survived the OAU and still prevails within the AU and African sub-regional organisations. Yet, complacency and even indifference should not be tolerated towards vote-rigging and fraudulent elections which should be assimilated to 'unconstitutional change of government' and dealt with accordingly.

Foreign and African democratic leaders should find it degrading to compromise with those who cling to power and refuse to be their accomplices in vote-rigging, electoral manipulations or frauds in order to defend or preserve their selfish interests.

Six, with the adoption of the African Charter on Democracy, Elections and Governance, a new right was added to peoples' rights under the African human rights system, namely the right to democracy, free and fair elections, and good governance. Any right is to be asserted and continuously championed. Otherwise, it will be forfeited. In a democracy, the people are sovereign and not the leaders. Without the people positioning themselves at the forefront of the struggle for democracy, elections will never be democratic in Africa, as elsewhere. Any violation of the norms and principles governing democratic elections should therefore be vigorously opposed and condemned as a war crime or a crime against humanity in the African context.

Seven, in the DRC, as in many other African countries, democratic elections really matter for democracy, development and peace. In the long and even short run, voterigging, violence, electoral manipulations and frauds are not beneficial to the winners of an election. As a result, the people may end up feeling tired of voting with ballot papers and rather resolve to vote with their feet, AK47, and machetes, as this happened or is still happening in a number of African countries. Some people tend to resort to rebellions and wars to make change in the government since violence seems to be the language that most African authoritarian leaders understand and which has the support of the prominent members of the international community. Democratic elections are likely to spare Africa political violence and contribute to peace and development on the continent.

Eight, despite the veneration that we might and we do have as lawyers for the rule of law, we should acknowledge that general and impartial norms, principles, and standards alone do not make democratic elections or constitute a panacea to all electoral problems we are faced with in Africa. No matter how perfect and critical it may be, no legal and institutional framework will ever suffice to make democratic elections.

Africa needs political leaders (both in the majority and the opposition) who are fully committed to democracy, understand the rules of the electoral game, and accept to abide by them. This commitment is also required from the members of the judiciary, the electoral commission, the administration, the army, the police, and other security services who should be competent and professional women and men of integrity above parties' politics.

Finally, it is worth stressing that democracy being the government of the people for the people and by the people as US President Abraham Lincoln defined it in his famous Gettysburg Address delivered on 19 November 1863, no one will ever champion democracy and democratic elections better than the people themselves. African people, including those in civil society organisations, academic institutions, churches, unions, political parties, the private sector, and the media, should continuously stand ready to 
fight for democracy and even die for it as one of their fundamental rights. They should ensure that norms and principles promoting democratic elections are entrenched in their national constitutions and legislation and states' institutions and political leaders abide by them. They should oppose any vote-rigging and electoral frauds as a crime against their humanity.

Elections are costly, but their importance in our modern democracy is beyond dispute. Accordingly, the question is not whether elections matter or not, but what to do to make them democratic and ensure that they contribute to democratic consolidation. As for Bratton and Posner, ${ }^{85}$ formal procedures for elections do not create a democracy. In our modern era, one can have elections or multipartyism without democracy, but it is difficult, if not impossible, to consider that modern democracy can go without them. ${ }^{86}$ To coin a metaphor from Ben Yahmed, elections and multipartyism are necessary ingredient of democracy like salt is to the meal in the kitchen. However, salt alone does not make a meal. Ben Ahmed warned that those African peoples who would content themselves with multipartyism and elections would not take long to be disappointed. ${ }^{87}$

In Africa as Asia and South America, for instance, experience has shown that elections can co-exist with systematic abuses of human rights and disenfranchisement of large segments of the population and authoritarianism may tie the knot with elections and multipartyism and even often does so. ${ }^{88}$

African people have no interest in 'voting without choosing, ${ }^{89}$ resulting in 'choiceless,, 'impoverished', 'cosmetic'92 democracy, 'démocratie sans le peuple', 'particracy', 'plutocracy, ${ }^{93}$ or 'electocracy'. ${ }^{94}$ Unfortunately, as compared to the 30 July 2006 elections, the DRC 28 November 2011 elections constituted a step backward when one could expect that they would contribute to democratic consolidation in this country.

Elections on the continent are already too costly. To give them a sense and prevent the people from resorting to other methods of 'voting' that are detrimental to peace, development, state reconstruction and national reconciliation, African leaders, people, foreign powers, international organisations have all interest in holding democratic, free and fair elections that would bring about or result in change instead of maintaining the status quo.

\section{Bibliography}

Act no. $07 / 008$ of 4 December 2007 related to the status of the political opposition in the Democratic Republic of Congo (DRC).

Act no. $10 / 013$ of 28 July 2010 related to the organisation and functioning of the National Independent Electoral Commission (NIEC).

Act no. 11/003 of 25 June 2011 amending Act no. 06/006 of 9 March 2006 related to the organisation of presidential, parliamentary, provincial, urban, municipal, and local elections, RDC Official Journal no. 13 of 1st July 2011.

Act of Parliament no. 11/014 of 17 August 2011 on the distribution of seats per electoral constituency for the parliamentary and provincial elections.

African Charter on Democracy, Elections, and Governance (ACDEG), adopted on 30 January 2007, and entered into force on 15 February 2012.

African Convention on Preventing and Combating Corruption (CPCC) adopted on 11 July 2003 and came into force on 5 August 2007.

African Union (AU) Constitutive Act adopted July 2000 and entered into force in May 2001. 
Ake, C.L. (1996) Democracy and Development in Africa, The Brookings Institution, Washington, DC.

Bauer, G. (1999) 'Challenges to democratic consolidation in Namibia', in Joseph, R. (Ed.): State, Conflict and Democracy in Africa, Lynne Rienner Publishers, Boulder \& London.

Bratton, M. and Posner, D.N. (1999) 'A first look at second elections in Africa with illustrations from Zambia', in Joseph, R. (Ed.): State, Conflict and Democracy in Africa, Lynne Rienner Publishers, Boulder \& London.

Constitution of the Democratic Republic of Congo (DRC), Kinshasa, 18 February 2006.

Constitution of the Democratic Republic of Congo as amended on 20 January 2011.

Decision no. 002 bis/CENI/BUR/12 of 26 January 2012 related to the nullification of the elections of National Deputies of 28 November 2012 in the DRC.

Decision no. 002/CENI/BUR/12 of 26 January 2012 related to the publication of the provisional results of the election of National Deputies of 28 November 2012 in the DRC.

Decision no. 017/CENI/BUR/11 of 30 April 2011 related to the publication of the timetable of the electoral process $2011-2011$ in the DRC.

Decision no. 020/CENI/BUR/12 of 19 June 2012 amending Decision no 002/CENI/BUR/12 of 26 January 2012 related to the publication of the provisional results of the election of National Deputies of 28 November 2012 in the DRC.

Decision no. $057 / \mathrm{CENI} / \mathrm{BUR} / 11$ of 15 September 2011 related to the publication of the provisional list of the candidates to the presidential election of 28 November 2011 in the DRC.

Decision no. 058 /CENI/BUR/11 of 20 September 2011 related to the publication of the provisional list of the candidates to the election of National Deputies of 28 November 2011 in the DRC.

Decision no. 059/CENI/BUR/11 of 26 September 2011 related to the publication of the final list of the candidates to the presidential election of 28 November 2011 in the DRC.

Decision no. 064/CENI/BUR/10 of 14 October 2011 related to the publication of the final list of the candidates for the election of National Deputies of 28 November 2011 in the DRC.

Declaration on Democracy, Political, Economic, and Corporate Governance (DPECG), adopted by the AU Assembly of Heads of State and Government in Durban, South Africa, in July 2002.

Duverger, M. (1976) La démocratie sans le peuple, Armand Colin, Paris.

Elections of 28 November 2011 in the Democratic Republic of Congo [online] http://www.ceni.gouv.cd (accessed 30 June 2012).

Electoral Act no. 06/006 of 9 March 2006 relating to the organisation of presidential, legislative, urban, municipal and local elections.

Electoral Act no. 11/003 of 25 June 2011 amending Act no 06/006 of 9 March 2006 related to the organisation of presidential, parliamentary, provincial, urban, municipal, and local elections, RDC Official Journal no 13 of 1st July 2011.

Gonidec, P.F. (1993) 'Démocratie et développement en Afrique: perspectives internationales ou nationales', Afrique 2000, No. 14.

Judgement of the Supreme Court of Justice R. CONST 148/TSR of 25 February 2011.

Judgments of the Supreme Court of Justice nos. RCE 474/DN, 479/DN, 488/DN, 695/697/DN, 750/DN, and 605/629/DN of 24 April 2012.

Mangu, A.M.B. and Budeli, M. (2008) 'Democracy and elections in the Democratic Republic of Congo: lessons for Africa', Law, Democracy \& Development, Vol. 12, No. 1.

Mission Nationale d'Observation (2011) Observation de la Compilation des Elections Législatives du 28 Novembre 2011, Décembre, Kinshasa.

Mkandawire, T. (1999) 'Crisis management and the making of 'Choiceless democracies", in Joseph, R. (Ed.): State, Conflict and Democracy in Africa, Lynne Rienner Publishers, Boulder \& London.

Obama, B. (2008) The Audacity of Hope. Thoughts on Reclaiming the American Dream, Vintage Books, 1st ed., New York. 
Ordinance no. 11/012 of 3 February 2011 related to the inauguration of the members of the Bureau of the National Independent Electoral Commission.

UNC v Kabila Kabange Joseph \& Electoral National Independent Commission, 12 December 2011.

\section{Notes}

AU Constitutive Act (2000), Preamble.

AU Constitutive Act (fn 1 above) art 3 (g).

AU Constitutive Act (fn 1 above) art 4 (m).

The CPCC was adopted on 11 July 2003 and came into force on 5 August 2007.

CPCC (fn 4 above) art 7 (4).

CPCC (fn 4 above) art 16 (1) (b).

CPCC (fn 4 above) art 10 (b).

CPCC (fn 4 above) art 10 (a).

CPCC (fn 4 above) art 9 (5).

10 This Declaration was adopted by the AU Assembly of Heads of State and Government in Durban, South Africa, in July 2002, to govern the work of the APRM. The APRM was established later as a voluntary mechanism to assess and make recommendations to improve governance among AU member states participating in the New Partnership for Africa's Development (NEPAD) and that had also adhered to this mechanism.

11 The ACDEG was adopted on 30 January 2007 and came into force on 15 February 2012.

12 DRC Constitution of 18 February 2006.

13 Mangu, A.M.B. and Budeli, M. (2008) 'Democracy and elections in the Democratic Republic of Congo: lessons for Africa', Law, Democracy \& Development, Vol. 12, pp.93-116.

14 DRC 2006 Constitution (fn 12 above) art 2.

15 DRC 2006 Constitution (fn 12 above) art 226.

16 DRC 2006 Constitution (fn 12 above) art 198.

17 DRC 2006 Constitution (fn 12 above) art 197.

18 DRC 2006 Constitution (fn 12 above) art 226.

19 DRC 2006 Constitution (fn 12 above) arts 2, 3, and 4.

20 Mangu \& Budeli (fn 13 above) 96-97.

21 DRC 2006 Constitution (fn 12 above) art 1.

22 DRC 2006 Constitution (fn 12 above) art 6; Mangu \& Budeli (fn 13 above) 96.

23 DRC 2006 Constitution (fn 12 above) art 6; Mangu \& Budeli (fn 13 above) 96.

24 DRC 2006 Constitution (fn 12 above) art 7; Mangu \& Budeli (fn 13 above) 96.

25 AU Constitutive Act (fn 1 above) art 4 (p).

26 DRC 2006 Constitution (fn 1 above) art 64.

27 DRC 2006 Constitution (fn 12 above) art 8; Mangu \& Budeli (fn 13 above) 96.

28 Act no 07/008 of 4 December 2007 related to the status of the political opposition, arts 1-31.

29 DRC 2006 Constitution (fn 12 above) art 5; Mangu \& Budeli (fn 13 above) 97.

30 DRC 2006 Constitution (fn 12 above) art 5; Mangu \& Budeli (fn 13 above) 96.

31 DRC 2006 Constitution (fn 12 above) title 2.

32 DRC 2006 Constitution (fn 12 above) arts 68-71.

33 DRC 2006 Constitution (fn 12 above) arts 101-103. 
DRC 2006 Constitution (fn 12 above) arts 104-106.

DRC 2006 Constitution (fn 12 above) art 100.

DRC 2006 Constitution (fn 12 above) art 197.

37 Electoral Act no 06/006 of 9 March 2006 relating to the organisation of presidential, legislative, urban, municipal and local elections (2006) arts 158-173, 198 al 2, 235; Mangu \& Budeli (fn 13 above) 98.

38 DRC 2006 Constitution (fn 12 above) art 70.

39 DRC 2006 Constitution (fn 12 above) arts 70-71, 101-103, 104-106, 197-198; 2006 Electoral Act (fn 37 above) arts 100-114, 128-142, 143-157, 158-173, 223-235; Mangu \& Budeli (fn 13 above) 97-98.

40 DRC 2006 Constitution (fn 12 above) art 70.

41 DRC 2006 Constitution (fn 12 above) art 5; Mangu \& Budeli (fn 13 above) 96.

42 DRC 2006 Constitution (fn 12 above) arts 101, 104, and 197.

43 Mangu \& Budeli (fn 13 above) 96.

44 Act no 11/002 of 20 January 2011 amending some provisions of the Constitution of the Democratic Republic of Congo of 18 February 2006.

45 Act no 11/002 (fn 44 above) art 71.

46 Act no 11/002 (fn 44 above) art 226.

47 Act no 11/002 (fn 44 above) arts 197-198.

48 DRC 2006 Constitution (fn 12 above) art 211.

49 DRC 2006 Constitution (fn 12 above) art 212.

50 DRC 2006 Constitution (fn 12 above) art 211 and 212.

51 DRC 2006 Constitution (fn 12 above) art 158.

52 DRC 2006 Constitution (fn 12 above) arts 160-162, 216.

53 DRC 2006 Constitution (fn 12 above) art 161.

54 DRC 2006 Constitution (fn 12 above) art 168.

55 DRC 2006 Constitution (fn 12 above) art 223.

56 Electoral Act no 11/003 of 25 June 2011 amending Electoral Act no 06/006 of 9 March 2006 relating to the organisation of presidential, legislative, urban, municipal and local elections, RDC Official Journal no 13 of 1st July 2011.

57 Electoral Act (fn 37 above).

58 Mangu \& Budeli (fn 13 above) 97-98.

59 Electoral Act (fn 37 above) arts 100-114, 158-173, 221, 223, 235; Mangu \& Budeli (fn 13 above) 97-98.

60 Electoral Act (fn 37 above) arts 115-127, 128-142, 143-157, 175, 193, 209, 224-232; Mangu \& Budeli (fn 13 above) 98.

61 Act no $10 / 013$ of 28 July 2010 related to the organisation and functioning of the NIEC.

62 DRC 2006 Constitution (fn 12 above) art 70 as amended on 20 January 2012.

63 Ordinance no 11/012 of 3 February 2011 related to the inauguration of the members of the Bureau of the NIEC.

64 Judgement of the Supreme Court of Justice R. CONST 148/TSR of 25 February 2011.

65 Decision no $017 / \mathrm{CENI} / \mathrm{BUR} / 11$ of 30 April 2011 related to the publication of the timetable of the electoral process 2011-2011 in the DRC.

66 Electoral Act (fn 56 above).

67 Act of Parliament no 11/014 of 17 August 2011 on the distribution of seats per electoral constituency for the parliamentary and provincial elections. 
68 Decision no 057/CENI/BUR/11 of 15 September 2011 related to the publication of the provisional list of the candidates to the presidential election.

69 Decision no 058/CENI/BUR/10 of 20 September 2011 related to the publication of the provisional list of the candidates to the election of National Deputies.

70 Decision no 059/CENI/BUR/11 of 26 September 2011 related to the publication of the final list of the candidates for the presidential election.

71 Decision no 064/CENI/BUR/10 of 14 October 2011 related to the publication of the final list of the candidates for the election of National Deputies.

72 http://www.ceni.gouv.cd (accessed on 30 June 2012).

73 http (fn 73 above).

74 UNC v Kabila Kabange Joseph \& Electoral National Independent Commission, 12 December 2011.

75 Ibid.

76 http (fn 73 above).

77 Decision no 002/CENI/BUR/12 of 26 January 2012 related to the publication of the provisional results of the election of National Deputies of 28 November 2012 in the DRC.

78 Decision no 002 bis/CENI/BUR/12 of 26 January 2012 related to the nullification of the elections of National Deputies of 28 November 2012 in the DRC.

79 These parties or political groupings include AHUDE, AJDS, CF, CODELI, DC, DDC, ENVOL, FIDEC, FNI, FONUS, FCDD, FSIR, MCSD, MIR, MLP, MSC, NBP, ODAPR, PA, PANADI, PANU, PAR, PARC, PARECO/PAP, PCBG, PECO, PNR, PNRD, PT, PTL, RADESO, RCD/N, RDPR, UCL, UDN, UDPS/Kibassa, ULDC, ULPD, UN, UNADEC, UNIR, and USC.

80 Judgments of the Supreme Court of Justice nos RCE 474/DN, 479/DN, 488/DN, 695/697/DN, 750/DN, and 605/629/DN of 24 April 2012.

81 DRC 2006 Constitution (fn 12 above) art 168.

82 Decision no 020/CENI/BUR/12 of 19 June 2012 amending Decision no 002/CENI/BUR/12 of 26 January 2012 related to the publication of the provisional results of the election of National Deputies of 28 November 2012 in the DRC.

83 Mission National d'Observation, Observation de la Compilation des Elections Législatives du 28 Novembre 2011 (2011) 2.

84 UNC v Kabila Kabange Joseph \& Electoral National Independent Commission (fn 75 above).

85 See Bratton, M. and Posner, D.N. (1996) 'A first look at second elections in Africa with illustrations from Zambia', in Joseph, R. (Ed.): State and Conflict in Africa, pp.378-379, Lynne Rienner Publishers, Boulder, London; Budeli \& Mangu (fn 13 above) 108.

86 See Bauer, G. Challenges to Democratic Consolidation in Namibia, in Joseph (fn 87 above) 439-441; Bratton \& Posner (fn 87 above) 379.

87 Gonidec, P.F. (1993) 'Démocratie et développement en Afrique: perspectives internationales ou nationales', Afrique 2000, Vol. 14, pp.57-58.

88 See Bratton \& Posner (fn 87 above) 378-379; Budeli \& Mangu (fn 13 above) 108.

89 Ake, C.L., Democracy and Development, 137.

90 Mkandawire, T., 'Crisis management and the Making of 'Choiceless democracies', in Joseph (fn 87 above) 119-135.

91 Ake (fn 91 above) 130, 132, 137.

92 Ake (fn 91 above) 130.

93 Duverger, M., La démocratie sans le peuple (1976), Armand Colin, Paris.

94 Obama, B. (2008) The Audacity of Hope. Thoughts on Reclaiming the American Dream, p.375, Vintage Books, 1st ed., New York. 